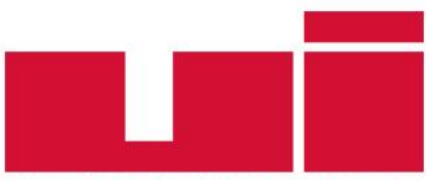

ULLUSLARARASIILIȘKiLER

Akademik Dergi

Yayın ilkeleri, izinler ve abonelik hakkında ayrıntılı bilgi:

E-mail: bilgi@uidergisi.com.tr

Web: www.uidergisi.com.tr

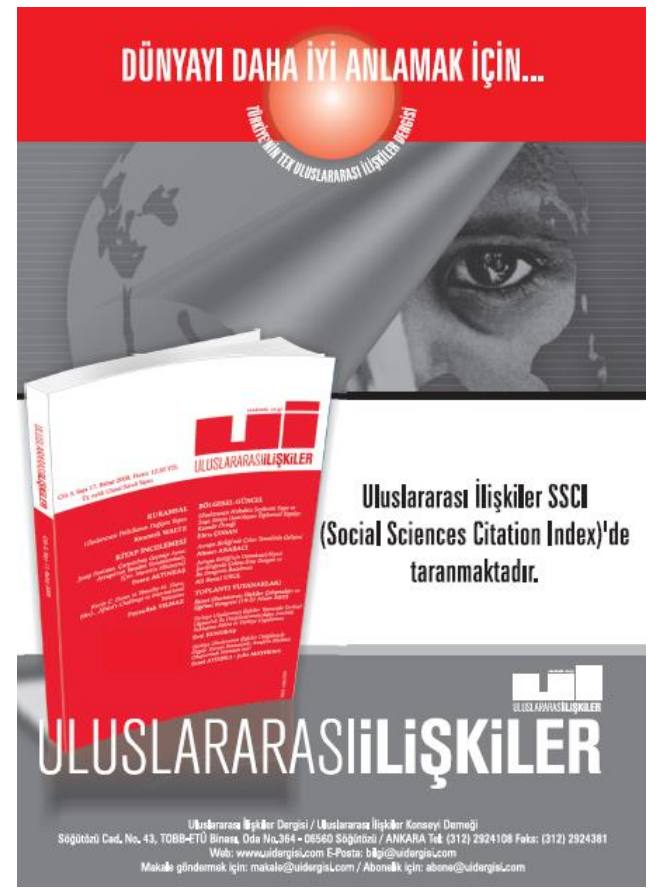

TWAIL ve Yeni Bir Hâkimiyet Aracı Olarak Koruma Sorumluluğu (R2P): Libya Örneği

\author{
Tuğçe KELLECI* ve Marella BODUR ÜN** \\ * Arş. Gör., Uluslararası İlişkiler Bölümü, Ankara Üniversitesi \\ ** Yrd. Doç. Dr., Siyaset Bilimi ve Uluslararası İlişkiler \\ Bölümü, Çukurova Üniversitesi
}

Bu makaleye atıf için: Kelleci, Tuğçe ve Bodur Ün, Marella, "TWAIL ve Yeni Bir Hâkimiyet Aracı Olarak Koruma Sorumluluğu (R2P): Libya Örneği“", Uluslararası İlişkiler, Cilt 14, Say1 56, 2017, s. 89-104.

Bu makalenin tüm hakları Uluslararası İlișkiler Konseyi Derneği’ne aittir. Önceden yazılı izin alınmadan hiç bir iletişim, kopyalama ya da yayın sistemi kullanılarak yeniden yayımlanamaz, çoğaltılamaz, dağıtılamaz, satılamaz veya herhangi bir şekilde kamunun ücretli/ücretsiz kullanımına sunulamaz. Akademik ve haber amaçlı kısa alıntılar bu kuralın dışındadır.

Aksi belirtilmediği sürece Uluslararası Illişkiler'de yayınlanan yazılarda belirtilen fikirler yalnızca yazarına/yazarlarına aittir. UİK Derneğini, editörleri ve diğer yazarları bağlamaz. 


\title{
TWAIL ve Yeni Bir Hâkimiyet Aracı Olarak Koruma Sorumluluğu (R2P): Libya Örneği
}

\author{
Tuğçe KELLECí \\ Arş. Gör., Uluslararası İlişkiler Bölümü, SBF, Ankara Üniversitesi, Ankara. \\ E-posta: tugce_kelleci@hotmail.com. \\ Marella BODUR ÜN \\ Yrd. Doç. Dr., Siyaset Bilimi ve Uluslararası İlişkiler Bölümü, İIBF, Çukurova Üniversitesi, Adana. \\ E-posta:marbodur@gmail.com. \\ Bu makale, Yrd. Doç. Dr. Marella Bodur Ün’ün danışmanlı̆̆ında Arş. Gör. Tuğçe Kelleci tarafından yazılan “Üçüncü Dünya \\ Yaklaşımları Işı̆̆ında Uluslararası Hukuk ve İnsani Müdahale: Libya Örneği” adlı Yüksek Lisans tezinden revize edilerek \\ hazırlanmıştır.
}

\begin{abstract}
ÖZET
Uluslararası Hukuka Üçüncü Dünya Yaklaşımları (Third World Approaches to International Law-TWAIL), günümüz uluslararası hukuk düzeni ile geçmişin sömürgecilik mirası arasında bağlantı kurmakta ve insani müdahale ile Koruma Sorumluluğu (Responsibility to Protect-R2P) gibi kavramları bu çerçevede yorumlamaktadır. Geleneksel analizler, insani müdahaleyi uluslararası hukuka uygunluk bağlamında tartışmakta ve Birleşmiş Milletler Güvenlik Konseyi (BMGK) kararlarına odaklanmaktadır. TWAIL ise, insan hakları ve demokrasi söylemleri ekseninde yapılan müdahaleleri tarihsel bir hukuk ve meşruiyet okumasıyla değerlendirmektedir. Bu bağlamda incelenen Libya müdahalesi, TWAIL'in uluslararası hukuka, insani müdahaleye ve R2P'ye ilişkin varsayımlarını tartışma fırsatını sunmaktadır. Bu makale, TWAIL’in geliştirdiği analiz çerçevesine dayanarak, Batı́nın Üçüncü Dünya’ya müdahale etmek için uluslararası hukuku ve R2P'yi nasıl araçsallaştırdığını ortaya koymaya çalışmaktadır.
\end{abstract}

Anahtar Kelimeler: Uluslararası Hukuka Üçüncü Dünya Yaklaşımları (TWAIL), İnsani Müdahale, Koruma Sorumluluğu (R2P), Libya Müdahalesi.

\section{TWAIL and the Responsibility to Protect (R2P) as a New Instrument of Domination: the Case of Libya}

\begin{abstract}
Third World Approaches to International Law (TWAIL) points to the interactions between international law and colonial legacy and problematizes the concepts of humanitarian intervention and the Responsibility to Protect (R2P) within this framework. Humanitarian intervention is usually discussed in relation to its legitimacy in international law and the United Nations Security Council (UNSC) resolutions. TWAIL, however, analyzes those interventions that are constructed through discourses of human rights and democracy, highlighting the importance of issues other than legality and legitimacy. A historical reading of the Libyan case through the prism of TWAIL not only provides us with an opportunity to assess TWAIL's assumptions in relation to international law, humanitarian intervention and R2P but also reveals how international law and R2P are used to legitimize interventions of the West into the Third World.
\end{abstract}

Keywords: Third World Approaches to International Law (TWAIL), Humanitarian Intervention, Responsibility to Protect (R2P), Intervention in Libya. 


\section{Giriş}

Dünya tarihinin ve siyasetinin en temel ögelerinden biri, Batı ile Üçüncü Dünya arasındaki eşitsiz, hiyerarşik ve ikincisi aleyhine işleyen uluslararası düzenin kendisini farklı biçimlerde devam ettirmesidir. Bu bağlamda, İkinci Dünya Savaşı sonrasında doğrudan kolonyal yönetimlerin yerini önce siyasi bağımsızlık ile iktisadi ve kültürel bağımlılık deneyimi, 1990'ların sonundan itibaren ise meşruiyetini uluslararası hukuktan alan müdahale pratikleri almıştır. Bir dönem Üçüncü Dünya, günümüzde Küresel Güney olarak da tanımlanan ülkelerin bir kısmında 2000’lerden itibaren iktisadi büyüme yaşanmasına rağmen müdahalenin siyasal yönü (Batı-Doğu ekseni) değişmemiştir.

Batı, hangi meşrulaştırıcı kavramla sunulursa sunulsun ve hangi uluslararası kurumda karara bağlanırsa bağlansın, son aşamada Doğu üzerindeki müdahale edebilme hakkını yeniden üreterek, ilişkilerin hiyerarşik doğasını ve bunun uzantısı olan yeni bir hâkimiyet biçimini kurabilmiştir. Böyle bir hâkimiyet ilişkisinin sürdürülebilmesi için egemenlik anlayışının dönüşmesi, müdahale ve sorumluluk kavramlarının yeniden tanımlanması gerekmiştir. Uluslararası Hukuka Üçüncü Dünya Yaklaşımları (Third World Approaches to International Law-TWAIL), bu tartışmalar konusunda önemli bir analiz çerçevesi sunmaktadır.

TWAIL, günümüz uluslararası hukuk işleyişinin, Üçüncü Dünya’nın kolonyal tecrübelerinden ayrı tutulamayacağını ileri sürerek, kolonyal tarihten miras kalan medeni-medenileşmemiş ayrımının uluslararası hukukta süregelen varlığını tartışmaya açmaktadır. Böyle bir analiz, taraflı egemenlik algısının, sistemdeki güç yapılarının belirleyiciliğinin, uluslararası hukuk düzenindeki hiyerarşik işleyişin ve hegemonik tutumun eleştirileri üzerine kurulmakta ve uluslararası hukukun Avrupamerkezci doğasına işaret etmektedir. TWAIL, insani müdahale ve Koruma Sorumluluğu'nu (Responsibility to Protect-R2P) da bu eleştiriler çerçevesinde yorumlamaktadır. Burada Batı'nın Üçüncü Dünya'ya müdahalesi "güç” ve “çıkar" unsurlarının ötesine geçmekte, kültürel ve aynı zamanda küresel hiyerarşi bağlamında yüklenilen bir misyona dönüşmektedir.

Ana akım yaklaşımlar, insani müdahale kararlarının hukuki boyutuna odaklanarak uluslararası hukukun ırksallaştırılmış ve hiyerarşik doğasını göz ardı etmektedir. ${ }^{1}$ Uluslararası sistem hukuki olarak egemen eşitlik ilkesine dayansa da hem devletler arasındaki siyasi, iktisadi ve askeri güç ilişkileri hem de bunun kültürel boyutu açısından hiyerarşiktir. Uluslararası hukuk, Üçüncü Dünya'ya yapılacak müdahaleleri meşrulaştırmak için kullanılabilmekte ve Batı́nın Üçüncü Dünya üzerindeki hâkimiyetini yeniden tanımlamasına imkân sunmaktadır. Müdahale edenin "kurtarıcı", müdahale edilenin ise "barbar" olarak kodlandığı bu süreç meşruiyet kazandıkça, Batı́nın müdahale pratikleri, dolayısıyla da uluslararası hiyerarşik düzen makul görülmekte ve daha az sorgulanmaktadır.

İnsani krizlere müdahale tartışmalarında, R2P'nin, sadece kararının alınış aşamasında değil müdahale sırasında ve sonrasındaki tüm boyutlarıyla incelenmesi gerekmektedir. Libya'ya ilişkin BMGK kararı önemli olmakla birlikte, müdahalenin hukuki ya da meşru tanımlanabilmesinin tek ölçütü değildir. Müdahale insani kriz söylemleriyle başlamakta fakat bir kez fiili durum gerçekleşince kendi dinamiğini yaratmakta, hukuksal boyut ile müdahalenin yarattığı sonuçlar arasında boşluklar oluşmaktadır.

1 Bkz. Makau W. Mutua, "What is TWAIL?, Proceedings of the 94th Anual Meeting of the American Society of International Law, 2000, s.31-38; Robert Knox, "Race, Racialisation and Rivalry in the International Legal Order”, Alexander Anievas, Nivi Manchanda ve Robbie Shilliam (der.), Race and Racism in International Relations: Confronting the Global Colour Line, Abingdon, Routledge, 2015, s.175-191. 
TWAIL yazarlarının gerek uluslararası hukuk gerekse insani müdahale konusundaki temel kaygıları Libya müdahalesinde büyük ölçüde gözlemlenmiştir. TWAIL çerçevesinde genel olarak insani müdahale ve R2P, özelde ise Libya müdahalesi analiz edildiğinde söz konusu müdahalenin sorun çözmekten uzak olduğu ve Batı́nın küresel üstünlüğünün bir aracına dönüştüğü sonucu ortaya çıkmaktadır. Bu çalışmada, insani krizlere müdahale etme sorunsalının Batı́nın müdahale etme hakkına dönüştügü, "insani müdahale” ve "koruma sorumluluğu” gibi özünde etik kaygılara dayanan kavramların Üçüncü Dünya’ya müdahalenin bir aracı haline geldiği ileri sürülmektedir.

\section{İnsani Müdahaleden “Koruma Sorumluluğu”na}

İnsani müdahale, ağır ve sistematik insan hakları ihlalleri ile karşı karşıya kalan halkların korunması amacıyla diğer devletlerin silahlı güç kullanarak müdahale etmesidir. ${ }^{2}$ Soğuk Savaş döneminde, uluslararası hukuk, devlet güvenliğini öncelikli hedef olarak tanımlayarak insani güvenliği göz ardı etmiştir. 20. yüzyılın sonlarında, güvenliğin referans nesnesinin insanı koruma amacına yönelik olarak genişlemesiyle, insani amaçlı uluslararası müdahalelerin uygunluğuna ilişkin tartışmalar ortaya çıkmıştır. Bu tartışmaların iki boyutundan birincisi insani müdahalenin hukuki dayanağına yoğunlaşırken, ikinci boyutu, insani müdahale kararının etik yönüne ilişkindir.

Devletler, BM Antlaşması madde 2/4 kapsamında, başka bir devlete karşı kuvvet kullanmamayı taahhüt etmişlerdir. Benzer şekilde madde $2 / 7$, başka devletlerin içişlerine karışmama ilkesini düzenlenmiştir. Ancak uluslararası barış ve güvenlik söz konusu olduğunda BMGK askeri müdahaleye varan tedbirler alabilecektir. Buna göre, BMGK tarafından, VII. bölüm kapsamında onaylanan insani müdahalelerin, içişlerine karışmama prensibiyle çelişmediği yönünde görüşler mevcuttur. ${ }^{3}$

Soğuk Savaş sonrası dönemde, insan hakları ihlallerinin insani müdahalelere gerekçe teşkil etmesiyle, egemenlik prensibinin aşınmaya başladığına ilişkin tartışmalar başlamıştır. Geleneksel anlamıla egemenlik, devletlerin toprakları üzerindeki mutlak hâkimiyetini ifade etmektedir. Günümüzde ise egemenlik, devletlerin hakkı olmaktan ziyade, sorumluluğu olarak tanımlanmakta, devlet egemenliği belirli koşullar altında sınırlandırılabilmektedir. ${ }^{4}$ İnsani müdahale söylemsel değişikliğe uğramış, egemenlik prensibini aşındıran "müdahale" kavramının yerini "sorumluluk" kavramı almıştır. Bu değişimin, insani müdahaleyi uygulamada ne ölçüde geliştirdiği ise tartışmalıdır.

NATO’nun BMGK onayı olmadan gerçekleştirdiği Kosova müdahalesini (1999) takiben, dönemin BM Genel Sekreteri Kofi Annan, bir taraftan BM yetkilendirmesi olmadan, bölgesel örgütlerin insani krizlere müdahalesinin hukukiliğini sorgularken, diğer taraftan insan haklarının sistematik olarak ihlal edildiği durumlara müdahale edilmemesi sorunsalını gündeme taşımıştır. ${ }^{5}$ Bu bağlamda, Kanada’nın öncülügünde 2000 yılında, Müdahale ve Devlet Egemenliği Uluslararası Komisyonu (International Commission on Intervention and State Sovereignty-ICISS) oluşturulmuştur.

2 Funda Keskin, “Darfur: Koruma Yükümlülüğü ve İnsancıl Müdahale Kavramları Çerçevesinde Bir İnceleme” Uluslararası İlişkiler, Cilt 6, No.21, 2009, s.70.

3 Yıldıray Sak, "Uluslararası Hukukta İnsancıl Müdahale ve Libya Örneği: Suriye’de Yaşanan ya da Yaşanacaklar için Dersler”, Uluslararast İlişkiler, Cilt 11, No.44, 2015, s.127.

4 Francis M. Deng et al., Sovereignty as Responsibility: Conflict Management in Africa, Washington D.C., The Brookings Institution, 1996; Georg Nolte, "Sovereignty as Responsibility?", American Society of International Law, No.99, 2005, s.389-392.

5 Kofi Annan, “Two Concepts of Sovereignty”, The Economist, 352, 1999, http://www.economist.com/node/324795 (Erişim Tarihi 4 Kasım 2014). 
Komisyon 2001'de yayımladığı raporda6 "Koruma Sorumluluğu” (R2P) kavramını geliştirerek uluslararası toplumun önceliklerini açıklamış ve askeri müdahalenin ilkelerini belirlemiştir. ${ }^{7}$

Rapora göre, vatandaşlarını felaketlerden koruma konusunda öncelikli sorumluluk ilgili devletlere aittir.Devletlerin bu sorumluluğu üstlenememesi veya üstlenmeyi istememesi durumunda, uluslararası toplumun sorumluluğu gündeme gelecektir. ${ }^{8}$ R2P, hem devlet egemenliğini kendi vatandaşlarının haklarını koruma kıstasına bağlamakta hem de "sorumluluk olarak egemenlik" kavramıyla insani müdahalenin, bazı durumlarda ahlaki zorunluluk olduğunu belirtmektedir. ${ }^{9}$ Buna göre, egemenlik iki yönlü bir sorumluluk alanına karşılık gelmektedir. Bu sorumluluk, hem devletlerin egemenlik hakkına saygıyı hem de insanların temel haklarının bu devletler tarafından korunmasını vurgulamaktadır. "Sorumluluk olarak egemenlik" kavramı, egemenliği devlet ile uluslararası toplum arasında ortak bir payda haline getirmekte, ${ }^{10}$ böylece egemenlik bir hak olmanın ötesine geçmekte ${ }^{11}$ ve insani krizleri önlemek için sınırlandırılabilmektedir.

ICISS raporuna göre, uluslararası toplumunüstlenmesigereken üçtemel sorumluluktan “önleme sorumluluğu", halkları tehlikeye atan krizlerin ve iç savaşların nedenlerine işaret etme sorumluluğu iken, "tepki gösterme sorumluluğu”, yaptırımlar ve adli takibat gibi zorlayıcı önlemleri ve askeri müdahaleyi içermektedir. "Yeniden inşa etme sorumluluğu" ise, müdahaleden sonra, müdahalenin durdurmayı/önlemeyi planladığı felaketin nedenlerine işaret edecek şekilde "iyileştirme”, "yeniden inşa etme" ve "uzlaştırma” süreçlerine karşllık gelmektedir. ${ }^{12}$

Raporda "tepki gösterme sorumluluğu” kapsamındaki askeri müdahalenin ilkeleri de ortaya konularak, bir yandan savaş gerekçeleri için "haklı neden eşiği” ( just cause threshold) belirlenirken diğer yandan müdahalenin çerçevesini oluşturacak "ihtiyati ilkeler" (precautionary principles) açıklanmıştır. Geniş çaplı "hayat kaybı" ve "etnik temizlik" müdahale etmeme prensibinin eşiğini aşan unsurlardır. Ayrıca müdahaleler, sadece BMGK kararıyla (doğru otorite) ve dört ihtiyati ilke doğrultusunda gerçekleştirilmelidir: insanların acı çekmesine son vermek için (doğru amaç); askeri olmayan tedbirler başarısız olmuşsa (son çare); müdahalenin süresi, yoğunluğu ve derecesi, insanları korumak için minimum ölçüdeyse (orantılılık) ve başarı umudu varsa (olumlu gelişme beklentisi). ${ }^{13}$

BM 2005 Dünya Zirvesi’nde devletler, halkları koruma sorumluluğunu evrensel bağlamda üstlendiklerini teyit etmişlerdir. BMGK’nın 1674 sayılı kararıla, 2005 Dünya Zirvesi Sonuç

6 ICISS, The Responsibility to Protect, Ottawa, International Development Research Centre, 2001, http:// responsibilitytoprotect.org/ICISS\%20Report.pdf, (Erişim Tarihi 10 Mayıs 2016).

7 İnsani krizleri önlemek için R2P gibi kavramlara ihtiyaç vardır. Ancak, R2P'nin hukuki ve meşru olarak tanımlanabilmesinin ölçütü siyasi amaçlar için kullanılmasının engellenmesidir. R2P'nin gelişen bir hukuk normu olup olmadığına ilişkin tartışma için bkz. Carsten Stahn, "Responsibility to Protect: Political Rhetoric or Emerging Norm?”, American Society of International Law, Cilt 101, No.1, 2007, s.99-120. R2P, devletler ve uluslararası toplum için davranış standardı oluşturan bir "uluslararası etik norm” olarak da tanımlanmaktadır. Bkz. Pınar Gözen Ercan, "R2P: From Slogan to an Ethical Norm”, Uluslararası İlişkiler, Cilt 11, No.43, 2014, s.35-52; Alex J. Bellamy, "The Responsibility to Protect Turns Ten", Ethics \& International Affairs, Cilt 29, No.2, 2015, s.161-185.

8 ICISS, The Responsibility to Protect, s.17, para. 2.30 ve para. 2.31 .

9 James Pattison, "Whose Responsibility to Protect? The Duties of Humanitarian Intervention", Journal of Military Ethics, Cilt 7, No.4, 2008, s.263.

10 Mohtaba Mahdavi, "A Postcolonial Critique of Responsibility to Protect in the Middle East", Perceptions, Cilt 20, No.1, 2015, s.9.

11 ICISS, The Responsibility to Protect, s. 8, para. 1.35. Ayrica bkz. Deng et al., Sovereignty as Responsibility.

12 ICISS, The Responsibility to Protect, s. XI.

13 Ibid. s. XII. 
Bildirgesi'nde ${ }^{14}$ kabul edilen hususlar onaylanmıştır. Ancak, Komisyon'un raporundan farklı olarak bildirgede R2P, soykırım, savaş suçları, etnik temizlik ve insanlığa karşı suç durumlarıyla sınırlandırılmış, BMGK’nın askeri müdahale konusunda tek yetkili olduğu teyit edilmiş, askeri müdahale için gerekli olan kriterler dışarıda bırakılmış ve yeniden inşa etme sorumluluğu gündeme alınmamıştır.

R2P'nin nasıl uygulanacağı ise 2009'da BM Genel Sekreteri Ban Ki-moon'un yayımladığı raporda somutlaşmıştır. Raporda, R2P'ye ilişkin üç sütunlu uygulama anlayışı geliştirilmiştir. Birinci sütuna göre, yurttaş olsun veya olmasın tüm sivil halkın soykırım, savaş suçları, etnik temizlik ve insanlığa karşı suçlardan korunması ilgili devletin sorumluluğundadır. İkinci sütunda, devletlerin bu sorumluluğu yerine getirememesi durumunda uluslararası toplumun desteğine dikkat çekilmektedir. Üçüncü sütuna göre ise, bir devlet halkını, uluslararası toplumun desteğine rağmen, söz konusu suçlardan koruyamadığı takdirde, sivil halkı koruma sorumluluğu uluslararası toplumun yetkisindedir. ${ }^{15}$ ICISS raporunda askeri müdahale, olağanüstü durumlarda, insanları korumak amacıyla son çare olarak başvurulacak müstesna ve olağandışı bir uygulama iken ${ }^{16}$, BM Genel Kurulu “zamanında, kararlı ve kolektif” eylem fikrine odaklanarak müdahale konusunda ICISS’e oranla daha esnek bir tutum sergilemiştir. ${ }^{17}$

R2P, "hukuka aykırı ama meşru müdahale” savının önünü kapatmak amacıyla geliştirilmiş ${ }^{18}$, tartışmayı müdahale etme hakkından koruma sorumluluğu noktasına taşımıştır. Ancak uluslararası toplum içinde bu sorumluluğu kimin ve ne şekilde üstleneceği yeterince açık değildir. ${ }^{19}$ Ayrıca Libya örneğinde R2P çerçevesinde yapılan müdahale oldukça tartışmalı bir seyir izlemiştir.

\section{Avrupa-merkezci Uluslararası Hukuka Karşı Bir Direniş: TWAIL}

Uluslararası hukuk ve sömürgecilik arasındaki tarihsel sürekliliği aydınlatmayı hedefleyen TWAIL’in, uluslararası hukuka yönelik eleştirileri belirli ilkeler üzerinden şekillenmektedir. Bu ilkeler, Avrupamerkezci olmayan bir evrenselliğin savunusu, hiyerarşi karşıtllğı, karşı-hegemonik duruş, Üçüncü Dünyacılık ve "teorik ittifak stratejisi"dir. ${ }^{20}$ Küresel düzendeki adaletsizliği ve eşitsizliği ortadan kaldırmayı hedefleyen TWAIL, hem uluslararası hukukun evrensellik vurgusuna yönelik bir karşı hareketi ("direniş") hem de yeni bir uluslararası hukuk düzeni talebini (reform) yansıtmaktadır. ${ }^{21}$ TWAIL'in temel amacı, "Avrupalı olmayanları Avrupalıların hâkimiyetine sokan uluslararası normların

14 UNGA, "2005 World Summit Outcome”, 24 Ekim 2005, http://www.un.org/womenwatch/ods/A-RES-60-1-E.pdf, (Erişim Tarihi 10 Mayıs 2015).

15 UNGA, “Implementing the Responsibility to Protect”, 12 Ocak 2009, http://responsibilitytoprotect.org/ implementing\%20the\%20rtop.pdf (Erişim Tarihi 15 Nisan 2015).

16 ICISS, The Responsibility to Protect, s.XII.

17 UNGA, "Implementing the Responsibility to Protect".

18 Sak, "Uluslararası Hukukta İnsancil Müdahale”, s.140.

19 Pattison, “Whose Responsibility to Protect?”, s.263.

20 Ali Murat Özdemir, Güç Buyruk Düzen, Ankara, İmge, 2011, s.149-207. TWAIL-I ve TWAIL-II şeklinde sınıflandırılan TWAIL'in, benzerliklerine rağmen, ayrıldıkları temel noktalar bulunmaktadır. TWAIL-I, Üçüncü Dünya devletlerinin egemenliğini analizin merkezine yerleştirirken, TWAIL-II Üçüncü Dünya toplumlarının çıkarlarını analize dâhil etmektedir ve bu toplumları, Üçüncü Dünya devletlerinden bağımsız düşünmektedir. Bkz Mutua, “What is TWAIL?”, s.31; Luis Eslava ve Sundhya Pahuja, "Between Resistance and Reform: TWAIL and the Universality of International Law”, Trade, Law and Development, Cilt 3, No.1, 2011; Usha Natarajan, The 2003 Iraq Invasion and the Nature of International Law: Third World Approaches to the Legal Debate, Unpublished doctoral dissertation, Canberra, Australian National University College of Law, 2008. Bu çalışmada, TWAIL yazını, ortak kökenleri ve eleştirileri çerçevesinde ele alınmıştır.

21 Eslava ve Pahuja, “Between Resistance and Reform”, s.105. 
ve kurumların ırksallaştırılmış hiyerarşisinin yaratılması ve sürdürülebilmesinde uluslararası hukukun bir araç olarak kullanımını anlamak ve yapı söküme uğratmak"tır. ${ }^{22}$ Böylece, uluslararası hukuku bir "baskı dili” olmaktan çıkarıp bir "özgürleştirme dili” haline getirebilmek ve küresel adaleti sağlayabilmektir. ${ }^{23}$

Kolonyal tarih, güç, kimlik, farklılık” gibi kavramların uluslararası hukukla ilişkisini tartışan TWAIL'e ${ }^{24}$ göre, yeni dünya düzeninde kolonyal hâkimiyet sürdürülemeyeceğinden, uluslararası hukuk kanalıyla yeni bir hâkimiyet yöntemi ortaya konulmuştur. ${ }^{25}$ Uluslararası hukuk, evrensellik, eşitlik ve adalet gibi kavramlarla harekete geçirilerek, Avrupalı olmayan devletleri, Avrupa hâkimiyetinde tutmak için etkili bir araç olarak kullanılmaktadır. Batı, "medenileştirme misyonu”26 çerçevesinde Avrupalı olmayan halkları, "barbar, geri kalmış, şiddet yanlısı" olarak nitelendirmekte, bu ötekileştirme ve hiyerarşi yaratılırken "ırk" kavramı belirleyici olmaktadır. ${ }^{27}$ Dahası, Avrupa medeniyeti, coğrafi, tarihsel, hukuki, ekonomik, politik söylem ve pratiklerin ürünü olmasına rağmen "hiçbir jeopolitik belirlenimi yokmuş gibi” davranmaktadır. ${ }^{28}$

TWAIL, uluslararası hukuk ve emperyalizm arasında kaçınılmaz bir ilişki saptamaktadır. ${ }^{29}$ Uluslararası hukukun tarafsızlık iddiasını eleştiren TWAIL’e göre, gerçeklik Batı'da üretilirken müdahalelerin merkezi her daim Doğu'dur. Uluslararası hukuk güçlünün güçsüzü hâkimiyeti altına almasının bir aracı olarak kullanılmakta, özellikle "insan hakları" ve "insanlığa karşı suç” söylemleriyle Üçüncü Dünya’ya yapılacak müdahalelere zemin hazırlanmaktadır. Üçüncü Dünya devletleri siyasi ve sosyoekonomik yapıları sebebiyle, iç anlaşmazlıklar ve dış müdahaleler konusunda savunmasız kalmakta ve uluslararası müdahalelerin nüfuz alanı haline gelmektedir.

Anghie'ye göre uluslararası hukuk, ırk temelinde yapılan medeni-medenileşmemiş ayrımı üzerinden şekillenmiştir. ${ }^{30}$ Bu bağlamda, Üçüncü Dünya devletlerine müdahalelerin önünü açan insani müdahale kavramı, bu devletlerin hâkimiyet altına alınabilmesi için kullanılan "medenileştirme misyonu"nun yeniden uyanışını temsil etmektedir. ${ }^{31}$ Mutua'nın insani müdahaleyi incelerken kullandığı "barbarlar, kurbanlar ve kurtarıcılar" metaforuna göre, Avrupa tarihine ve felsefi geleneklerine dayanan insan hakları söylemi, Üçüncü Dünya' ya yapılacak müdahalelerin temel yapıtaşı

22 Mutua, "What is TWAIL?", s.31.

23 Antony Anghie ve Bhupinder S. Chimni, "Third World Approaches to International Law and Individual Responsibility in Internal Conflicts", Chinese Journal of International Law, Cilt 2, No.1, 2003, s.79.

24 TWAIL'in teorik ve metedolojik nitelikleri üzerine bir analiz için bkz. Obiora Chinedu Okafor, "Critical Third World Approaches to International Law (TWAIL): Theory, Methodology, or Both?”, International Community Law Review, Cilt 10, 2008, s.371-378.

25 James Thuo Gathii, “TWAIL: A Brief History of Its Origins, Its Decentralized Network, and a Tentative Bibliography”, Trade Law and Development, Cilt 3, No.1, 2011, s.26-64.

26 Medenileştirme misyonunun harekete geçirilebilmesi için bir “öteki”ne ihtiyaç vardır ve bu ötekini Avrupalı olmayan halklar/devletler oluşturmaktadır.

27 Anghie ve Chimni, "Third World Approaches to International Law” s.85.

28 Gayatri Chakravorty Spivak, “Madun Konuşabilir mi?”, Dilek Hattatoğlu ve Gökçen Ertuğrul (der.), Méthodos: Kuram ve Yöntem Kenarından, İstanbul, Anahtar Kitaplar, 2009, s.54.

29 Robert Knox, "Civilizing Interventions? Race, War and International Law", Cambridge Review of International Affairs, Cilt 26, No.1, 2013, s.111-132; Antony Anghie, Imperialism, Sovereignty and the Making of International Law, Cambridge, Cambridge University Press, 2004; Makau W. Mutua, "Savages, Victims, and Saviors: The Metaphor of Human Rights", Harvard International Law Journal, Cilt 42, No.1, 2001, s.201-245; Balakrishnan Rajagopal, International Law from Below: Development, Social Movements and Third World Resistance, Cambridge, Cambridge University Press, 2003.

30 Anghie, Imperialism.

31 Sue Robertson, “'Beseeching Dominance': Critical Thoughts on the 'Responsibility to Protect' Doctrine”, Australian International Law Journal, Cilt 12, 2005, s.45. 
olarak kullanılmaktadır. ${ }^{32}$ Metaforda, Avrupalı olmayan kültürler, insan hakları ihlallerinin merkezi oldukları gerekçesiyle medenileştirilmesi gereken barbarlar olarak resmedilmektedir. Metaforun ikinci boyutunu, barbar kültürler yüzünden güçsüz olan kurbanlar oluşturmaktadır. Buna göre, dışarıdan müdahaleyle söz konusu mağduriyet koşullarının üstesinden gelinebilir. Metaforun üçüncü aşamasında ise Avrupalı devletler ve kurumlar, kurbanları kurtarmak için barbarları medenileştirecek kurtarıcılar olarak tanımlanmaktadır. Neticede, medeni-medenileşmemiş ayrımının temelinde ırksal ve kültürel ötekileştirme vardır ve emperyalizm bu ötekileştirme üzerinden yürütülmektedir. ${ }^{33}$

Robert Knox,a göre irksallaştırma (racialization), ezilen ve sömürülenlerin, kendilerini ezen ve sömürenler tarafından aşağıda (inferior) görüldüğü bir bölünmeye işaret etmektedir. Hukuki formları "ırksallaştıran" anlayış, uluslararası hukukun koruması dışında kalan "ötekiler” yaratmaktan ziyade emperyalist güçler ve müttefikleri için hareket alanı açmaktadır. Burada temel mesele, kimin kime müdahale edeceği olmaktan çıkmakta; kimin müdahale etmeye izni olduğuna dönüşmektedir. Böylece uluslararası hukuk, ırksallaştırılmış ötekilerin benzer gerekçelerle kuvvet kullanmasını sınırlandırmanın yolu haline gelmekte ve bu ilişkinin yeniden üretilmesinde belirleyici olmaktadır. ${ }^{34}$

Tarihsel olarak "medeni-medenileşmemiş" etiketlerinin yerine getirdiği işlevi, R2P kapsamında "insan hakları ihlalcisi” ve "otoriter rejim" tanımlamaları üstlenmektedir. ${ }^{35}$ Bu söylemlerle iki kültür arasında derin bir boşluk yaratılmakta, bir yanda evrensel ve medeniler, diğer yanda ise yerel (particular) ve medenileşmemiş olanlar resmedilmektedir. ${ }^{36}$ Bu bağlamda, irksal ötekileştirme, uluslararası hukukta güç kullanımının merkezine yerleşmektedir. ${ }^{37}$

TWAIL'in, Üçüncü Dünya'ya yapılan müdahalelere iki temel eleştirisi söz konusudur. ${ }^{38}$ Birincisi, güçlü devletlerin zayıf devletlere müdahalesine izin verilerek, mevcut uluslararası güç yapılarının meşrulaştırılmasıdır. İkincisi, yeniden inşa etme sorumluluğu ve kalkınma söylemiyle, güçlü devletlerin kendi siyasal ve ekonomik yönelimlerini yeniden kurmalarına izin verilmesidir. ${ }^{39}$

Bunun dışında, Batılı devletlerin, insani müdahale vakalarında seçici davrandığı söylenebilir. Örneğin R2P, Gazze'deki insani krizi önleyebilmek için bir çerçeve oluşturabilecekken ${ }^{40}$, bu seçenek değerlendirilmemiştir. Her ne kadar R2P bağlamında tanımlanan "kitlesel mezalim" (mass atrocity) kategorisine denk düşmese de, Gazze ablukası açık bir "kolektif cezalandırma” (collective punishment)

32 Mutua, "Savages, Victims, and Saviors" s.214-216.

33 Knox, “Civilizing Interventions?”, s.113.

34 Knox, "Race, Racialisation and Rivalry in the International Legal Order”, s.175-191.

35 Robertson, "Beseeching Dominance", s. 46.

36 Güncel bir örnek olarak, ABD Başkanı Donald Trump’’n ABD’nin Suriye’ye saldırısına ilişkin yaptığı açıklama verilebilir. Açıklamada, ABD'ye Suriye konusunda destek verecek devletler "medeni uluslar" (civilized nations) olarak ifade edilmektedir. Bkz. "Transcript and Video: Trump Speaks about Strikes in Syria", The New York Times, 6 Nisan 2017, https://www.nytimes.com/2017/04/06/world/middleeast/transcript-video-trump-airstrikes-syria.html?_r=0, (Erişim Tarihi 08 Nisan 2017).

37 Knox, “Civilizing Interventions?”, s.115; Anghie, Imperialism.

38 TWAIL-I yazarları, egemen-eşitlik ve müdahale etmeme prensibine bağlı olup Üçüncü Dünya'nın egemenliğinin aşındırılmasına karşıyken, TWAIL-II yazını, Üçüncü Dünya halklarının çıkarlarının, devlet çıarlarının üstünde olduğunu vurgulamaktadır (bkz. Anghie ve Chimni, “Third World Approaches to International Law”, s.83). Ancak uluslararası hukuk devletlerden ayrı olarak halkların egemenliğini tanımadığından mevcut söylemle halkların haklarını korumak kolay olmayacaktır. Ayrıca bu halkları kimin temsil edeceği de açık değildir. Egemenlik kavramı insanlarla devletler arasında bağ kurduğundan müdahalelerle devletlerin egemenliğine zarar verilmesi, halkların egemenliğini de sarsacaktır. Bkz.Natarajan, The 2003 Iraq Invasion, s.254, 256.

39 Robertson, "Beseeching Dominance", s.43.

40 Pınar Gözen Ercan, "Responsibility to protect and inter-state crises: why and how R2P applies to the case of Gaza”, The International Journal of Human Rights, Cilt 19, No.8, 2015, s.1098-1111. 
örneği olarak yorumlanmaktadır. Uluslararası toplumun bu bağlamda, önleme sorumluluğunu harekete geçirmesi gerekmektedir. ${ }^{41}$

TWAIL, insani müdahaleyi uluslararası hukukun sömürgeci doğası, sistemdeki güç ilişkileri, yaratılan ekonomik eşitsizliklerle ilişkilendirmekte ve kültür, ırk, emperyalizm gibi kavramları hukuk çözümlemesine dâhil ederek ana akım yaklaşımlardan farklı bir bakış açısı geliştirmektedir. TWAIL’i pozitif uluslararası hukuk kavrayışından ayıran temel özellik, sömürge geçmişi ile onun çağdaş emperyal niteliği arasındaki ilişkiye dikkat çekerek tarihsel bir analizi üstlenmesi ve Üçüncü Dünya’nın kaygılarını dile getirmesidir.

TWAIL, her ne kadar "gücün rolünü (realizm), sübjektif faktörleri (inşacılık), kurumların (kurumsalcılık) ve iç siyasetin rolünü (liberalizm) yadsımasa da uluslararası ekonomik ilişkilere vurgu yapmakta" ${ }^{42}$ ve devlet-merkezli realizmi sorgulamaktadır. ${ }^{43}$ Yerel karşısında evrenseli öncelemeyi reddetmesi, farklılık ve çoğulluklara vurgu yapması, yapı sökümünü analitik bir araç olarak kullanması onu her ne kadar postmodernizme yaklaştırsa da; Üçüncü Dünya'yı bir siyasal hareket ve madunun sesi olarak kavrayarak özcülük-karşıtlığına (anti-essentialism) bağlanmaması, analizde ampirik kanıt kullanımını teşvik etmesi, Küresel Güney için adalet arayışına bağlılıklarıyla ahlaki görelilikten uzaklaşması ve özellikle uluslararası hukukun yeniden inşası projesinin merkezi bir unsuru olması gibi nitelikleri dolayısıyla postmodernizmden ayrılmaktadır. ${ }^{44}$

Bununla birlikte, TWAIL’e yönelik bazı eleştiriler de vardır. S. G. Sreejith, TWAIL tartışmalarına daha felsefi bir açıdan yaklaşarak, TWAIL yazarlarının tarihe aşırı vurgu yapmakla kalmadığını aynı zamanda tarihin de TWAIL'i yanlış yönlendirdiğini ifade etmektedir. Geçmişin gereğinden fazla bugüne taşınması diyalektik olarak ters bir etki yaratıp, Batı ötekiliğini TWAIL'in içine yerleştirmekte ve Batı'ya hizmet etmektedir. Sreejith, TWAIL'i sadece eleştirmekle kalmaz, ona alternatif bir manifesto da geliştirmeye çalışır. Burada, tarihin, Batı'yı dışarıda bırakan bir dünya düzeni için revize edilmesine de, Batı'ya özel bir yer atfedilmesine de itiraz eder. ${ }^{45} \mathrm{John}$ D. Haskell ise, TWAIL'i, aşmaya çalıştığı sistemin kavramlarını kullanarak bir tartışma geliştirmeye çalışmakla eleştirmektedir. TWAIL’in uluslararası hukuku hem kolonyal döneminin ürünü hem de Üçüncü Dünya'nın özgürleşmesinin aracı olarak görmesinin önemli bir paradoks olduğunu ileri sürmektedir. ${ }^{46}$ TWAIL’e yönelik bir diğer eleştiri, TWAIL'in, ekonomi politiğin teorik üretim araçlarını kullanmaktan kaçınması ve bir önceki kuşak Üçüncü Dünyacılığından farklı olarak, kalkınma ve uluslararası ekonomik düzen arayışlarını göz $\operatorname{ard}_{1}$ etmesidir. $^{47}$

TWAIL'e yönelik eleştiriler çoğaltılabilir ancak bu eleştirilere rağmen, TWAIL, Üçüncü Dünyacılık anlayışına, uluslararası hukuka yeni bir bakış açısı kazandırmakta ve Üçüncü Dünya devletlerine yapılan insani müdahaleleri incelemek için kapsamlı bir analiz çerçevesi sunmaktadır.

41 Mahdavi, "A Postcolonial Critique", s.18.

42 Anghie ve Chimni, "Third World Approaches to International Law”, s.97.

43 Rajagopal, International Law from Below.

44 Andrew F. Sunter, “TWAIL as Naturalized Epistemological Inquiry”, Canadian Journal of Law and Jurisprudence, Cilt 20, No.2, 2007, s.488-489.

45 S. G. Sreejith, "An auto-critique of TWAIL's historical fallacy: sketching an alternative manifesto", Third World Quarterly, Cilt 37, No.11, 2016, s.2-4.

46 John D., Haskell, “TRALL-ing TWAIL: Arguments and blind spots in Third World Approaches to International Law”, Canadian Journal of Law and Jurisprudence, Cilt 27, No.2, s.1, 32.

47 Ali Murat Özdemir, Göksu Uğurlu ve Ebubekir Aykut, “Üçüncü Dünyacıllk Küreselleşirken?: Uluslararası Düzenlemenin Değişen Eleştirisi”, Amme İdaresi Dergisi, Cilt 45, No.1, Mart 2012, s.25-26. 


\section{TWAIL ve Libya Müdahalesi: “Tiranlar, Masumlar ve Koruyanlar”}

\section{Libya Müdahalesinin Gelişimi ve R2P}

Tunus'ta başlayan ve "Arap Baharı” olarak adlandırılan halk hareketleri, 15 Şubat 2011'de Bingazi'de bir insan hakları aktivistinin tutuklanmasıyla Libya’ya sıçramış, olaylar kısa sürede ülkenin diğer şehirlerine yayılmıştır. Olayların seyri, uluslararası toplumun Libya'da katliam yapıldığına dair inançlarını güçlendirerek Tunus ve Mısır sürecinde "izle ve gör” politikasını yürüten Batılı ülkeleri, bölge ülkelerini ve uluslararası aktörleri sürece dâhil etmiştir.

BMGK, BM Antlaşması'nın 41. maddesi uyarınca, "silahlı kuvvet kullanımını içermeyen” her türlü önlemi alma amacıyla 26 Şubat 2011'de 1970 sayılı karar1 ${ }^{48}$ almıştır. BMGK, Libya'ya ilişkin belirlediği eylem planını Arap Birliği’nin 12 Mart 2011 tarihli ve 7360 sayılı kararınca Konsey'e yaptığı çağrıya dayandırmaktadır. Libya hükümetinin meşruiyetini yitirdiğini belirten bu kararda, Arap Birliği, BMGK'den Libya'da uçuşa yasak bölge ilan etmesini ve Libya halkı ile orada ikamet eden yabancılar için güvenli bölgeler oluşturmasını istemektedir. ${ }^{49}$ BMGK, 1970 sayılı karardan kısa bir süre sonra, 17 Mart 2011'de, Libya hava sahası üzerinde uçuşa yasak bölge (no-fly zone) oluşturulmasına ve askeri bir müdahaleye izin veren 1973 sayılı kararı almıştır. ${ }^{50} 1973$ sayılı karar oldukça önemlidir; nitekim BMGK ilk defa R2P bağlamında askeri güç kullanımını içeren bir yetkilendirmeyi harekete geçirmiştir.

Her iki kararda da ağır ve sistematik insan hakları ihlallerine dikkat çekilmiş ve Libya otoritelerinin Libya halkını koruma sorumluluğu vurgulanmıştır. Uluslararası toplumun sorumluluğuna doğrudan bir atıf olmamakla birlikte, BM Antlaşması’nın VII. bölümü kapsamında Libya'daki olayların "uluslararası barış ve güvenliğe tehdit" olduğunun altı çizilmiş ve bu gerekçe güç kullanımını mümkün kılmıştır. 1973 sayılı kararla, 19 Mart 2011'de Fransa, İngiltere ve ABD önderliğinde müdahale başlatılmıştır. Karar, alınış biçimiyle uluslararası hukuka uygundur; ancak müdahale içeriği, uygulanış biçimi ve doğurduğu sonuçlar açışından incelenmelidir.

\section{Koruma Misyonundan Rejim Değişikliğine}

İnsani müdahale örneklerinde genel olarakgözlemlenen meşruiyet tartışması, müdahalenin amacından sapması ve hatta bazı durumlarda krizleri derinleştirmesi gibi sorunlar Libya müdahalesinde de görülmüştür. Uluslararası İlişkiler ve Uluslararası Hukuk disiplinlerindeki ana akım yaklaşımlar, Libya'ya müdahale kararının hukuki olup olmadığına yoğunlaşarak diğer önemli hukuki soruları cevapsız bırakmaktadır. Bu noktada asıl sorulması gereken Libya'ya müdahale sırasında ve sonrasında uluslararası hukukun nasıl bir rol oynadığıdır. Aynı soru tersten kurgulandığında müdahalenin uluslararası hukukun gelişimi açısından ne ifade ettiği de önem kazanmaktadır. Bu sorulara TWAIL perspektifinden yanıt aranması anlamlıdır; zira böyle bir analiz ana akımın görmezden geldiği konuların açı̆̆a çıkarılmasını mümkün kılabilir. ${ }^{51}$

48 UNSC, Resolution 1970 (S/RES/1970), http://www.icc-cpi.int/NR/rdonlyres/081A9013-B03D-4859-9D615D0B0F2F5EFA/0/1970Eng.pdf (Erişim Tarihi 10 Mayıs 2015).

49 Arab League, The Implications of the Current Events in Libya and the Arab Position (Res. No.: 7360), 12 Mart 2011, http:// www.lcil.cam.ac.uk/sites/default/files/LCIL/documents/arabspring/libya/Libya_19_Outcome_League_of_Arab_ States_Meeting.pdf (Erişim Tarihi 12 Mart 2015).

50 UNSC, Resolution 1973 (S/RES/1973), http://www.un.org/en/ga/search/view_doc.asp?symbol=S/RES/1973(2011) (Erişim Tarihi 10 Mayıs 2015).

51 Usha Natarajan, "A Third World Approach to Debating the Legality of the Iraq War", International Community Law Review, Cilt 9, 2007, s.405. 
TWAIL çerçevesinde yapılan analizin merkezinde egemenliğin yorumlanması yatmaktadır. TWAIL’e göre, görünürde adil olan egemenlik ilkesi gerçekte güçlü devletler tarafından uluslararası hukukun işleyişini şekillendirmede kullanılan bir araçtır. ${ }^{52}$ Bu bağlamda, Üçüncü Dünya devletlerinin egemenliği aşındırılabilir egemenlik; Batılı devletlerin egemenliği ise dokunulmaz egemenlik olarak tanımlanabilir. ${ }^{53}$ Üçüncü Dünya devletlerinin egemenliği sadece belirli koşullarda kabul görmekte, bu durum da, uluslararası hukukun Avrupa-merkezci bir yapıya sahip olduğu savını güçlendirmektedir.

TWAIL'in egemenlik üzerine geliştirdiği söylemle Libya'ya müdahale kararına ilişkin bazı devletlerin sunduğu çekinceler paralellik göstermektedir. Bu noktada, belirli devletlerin 1973 sayılı karara ilişkin tutumları dikkat çekicidir. Nitekim 1970 sayılı karar oybirliğiyle alınmışken, 1973 sayılı kararda Hindistan, Almanya, Brezilya, Rusya ve Çin çekimser kalmıştır. R2P çerçevesinde Libya'ya yapılacak askeri müdahaleyi hiçbir BMGK üyesi veto etmemiştir. Ancak çekimser kalan ülkelerin uluslararası toplumun çoğunluğunu yansıttığı ve kararın lehine oy kullanmadığı gözden kaçırılmamalıdır. ${ }^{54}$

Libya'daki durumun değerlendirildiği BMGK toplantısında, Hindistan temsilcisi, BM Antlaşması'nın VII. bölümünde yer alan zorlama tedbirlerinin kim tarafından harekete geçirileceği ve nasıl uygulanacağı konusunun açık olmadığını belirtmiştir. Konuşmanın temel vurgusu, Libya'nın egemenliğine, birliğine ve toprak bütünlügüne mutlak bağlılı̆̆ın olması konusuna yoğunlaşmıştır. ${ }^{55}$

İktisadi yaptırımları destekleme kararlılığındaki Almanya da, askeri tedbirler konusunda ihtiyatlı bir yaklaşım sergilemiştir. Kullanılacak askeri gücün risklerinin olduğunun altını çizen Alman temsilci, bunun büyük can kayıplarına neden olabileceğini belirtmiştir. Bu sebeple, Almanya, askeri seçenekleri desteklemediğini ve Alman güçlerinin olası bir askeri müdahaleye dâhil olmayacağını ifade etmiştir. ${ }^{56}$

Askeri operasyon fikrine yönelik çekinceleri olan Brezilya da, 1973 sayılı kararın 4. maddesinde belirtilen güç kullanımının, sivillere yönelik şiddeti engellemek yerine, tansiyonun yükselmesinde ve daha fazla zararın ortaya çıkmasında itici bir güç olacağı düşüncesindedir. Brezilya, yaşanan insani krizin önemine dikkat çekmekle birlikte Libya'ya askeri müdahalede bulunulmasına karşı çıkmıştır. ${ }^{57}$

BMGK daimi üyelerinden Rusya, Libya'ya askeri müdahale fikrine açı çekinceler sunan ülkelerden bir diğeridir. Rus temsilci, Konsey’in kararında, uçuşa yasak bölgenin nasıl oluşturulacağı ve güç kullanımının sınırlarının ne olacağı gibi konuların yeterince aydınlatılmadığını belirtmiştir. Rusya, ortak insani değerler nedeniyle kararı reddetmeyeceğini ancak Libya'da öncelikli amacın sivil halkın güvenliğini sağlamak, uzun vadeli bir istikrar ortamı yaratmak ve acilen ateşkes ilan etmek olduğunu bildirmiş ve kararda çekimser kalmıştır. ${ }^{58}$

BMGK'nın daimi üyesi Çin'in temsilcisi de, ülkesinin güç kullanımına her zaman karşı olduğunun altını çizmiş ve karara ilişkin, Çin’in ve diğer Konsey üyelerinin sorularının cevapsız

52 Anghie, Imperialism.

53 Bu çalışmada, analizi tam anlamıyla karşılaması sebebiyle "aşındırılabilir” ve "dokunulmaz" egemenlik kavramlarına yer verilmiştir. Bununla birlikte egemenlik tartışmalarına ilişkin literatürde farklı adlandırmalar ve tanımlamalar mevcuttur. Bkz. Richard N. Haas, “Sovereignty”, 20 Ekim 2009, http://foreignpolicy.com/2009/10/20/sovereignty/, (Erişim Tarihi 20 Mart 2017).

54 Mahdavi, "A Postcolonial Critique", s.19

55 UNSC, 6498th meeting, (S/PV.6498), http://www.un.org/en/ga/search/view_doc.asp?symbol=S/PV.6498 (Erişim Tarihi 15 Temmuz 2016).

56 Ibid.

57 Ibid.

58 Ibid. 
bırakıldığını belirtmiştir. Arap Birliği’nin uçuşa yasak bölge oluşturulması talebine büyük önem verdiğini beyan eden Çin, gerek Afrika Birliği gerek Arap Birliği gerekse Genel Sekreterlik adına hareket eden özel temsilci aracılığıyla atılacak her türlü barışçıl adımı destekleyeceğini ifade etmiştir. ${ }^{59}$

$\mathrm{Bu}$ çekinceler, TWAIL'in egemenlik konusundaki şüphelerini destekler niteliktedir. Zira çekinceler, müdahalenin kim tarafından, hangi amaçla ve ne şartlarda gerçekleştirileceğine odaklanmakta ve Libya’nın egemenliği ve toprak bütünlüğünün korunması ön planda tutulmaktadır. Ayrıca, Libya'ya hava saldırılarının başlamasının ardından, Arap Birliği Genel Sekreteri Amr Moussa, Libya'da yaşananların uçuşa yasak bölge uygulamasının ötesine geçtiğini belirtmekte ve amacın sivillerin bombalanması değil korunması olduğunu teyit etmektedir. ${ }^{60} \mathrm{Bu}$ söylemle de, 1973 sayılı kararın uygulama noktasında nasıl amacından saptığı ortaya konulmuştur.

Libya müdahalesine ilişkin bir diğer tartışma konusu müdahalenin hangi söylemler ve eylemlerle harekete geçirildiğidir. Libya’da koalisyon güçlerinin öncelikli hedefleri sivilleri korumak iken, 2011 yılının Mayıs ortasından itibaren bu hedef rejim değişikliğine yönelmiştir. ${ }^{61}$ Müdahaleye ilişkin Batı kaynaklı söylemler incelendiğinde uluslararası toplumun ilgisinin Kaddafi'yi devirmek fikrine yoğunlaştığı görülmektedir.

ABD Başkanı Barack Obama, İngiltere Başbakanı David Cameron ve Fransa Cumhurbaşkanı Nicolas Sarkozy, ortak kaleme aldıkları mektupta 1973 sayılı kararın temel hedefinin sivilleri korumak olduğunu, ancak Libya'da Kaddafi liderliğinde bir gelecek düşünmenin imkânı kalmadığını belirtmişlerdir. ${ }^{62}$ Hâlbuki her iki kararda da Libya'nın egemenliğine, toprak bütünlügüne ve ulusal birliğine zarar verilmeyeceğine yönelik güçlü beyanlarda bulunulmuştur. Gelinen noktada, Libya Dışişleri Bakanı Moussa Koussa’nın, BM kararları doğrultusunda, ateşkes ilan edileceğine ilişkin ifadeleri de dikkate alınmamıştır. ${ }^{63}$

TWAIL çerçevesinde Batılı devletlerin söylemleri de tartışmaya açılabilir. Libya'daki duruma ilişkin oluşturulan "pozitif söylem”, uluslararası toplumun Libya halkına karşı sorumluluğunu vurgulamakta, demokrasi ve insan hakları taleplerini gündeme taşımaktadır. Özgürlük, demokrasi ve insan hakları çağrıları, uluslararası toplum nezdinde, çatışmanın taraflarını, hükümetlerini devirmeye çalışan isyancılar olarak değil, temel hakları için savaşan bireyler olarak somutlaştırmakta ve askeri eylemler uluslararası kamuoyu tarafından kabul edilebilir bir çerçeveye taşınmaktadır. ${ }^{64}$

59 Ibid.

60 “Arab League chief slams air strikes", France 24, 21 Mart 2011, http://www.france24.com/en/20110321-arab-leaguechief-condemns-air-strikes-libya-moussa-mussa-no-fly-zone-un-resolution (Erişim Tarihi 10 Nisan 2017).

61 Simon Adams, "Libya and the Responsibility to Protect: Results and Prospects", 28 Mart 2014, http://www. globalpolicyjournal.com/blog/28/03/2014/libya-and-responsibility-protect-results-and-prospects (Erişim Tarihi 10 Mayıs 2015); Micah Zenko, "The Big Lie about the Libyan War", Foreign Policy, 22 Mart 2016, http://foreignpolicy. com/2016/03/22/libya-and-the-myth-of-humanitarian-intervention/ (Erişim Tarihi 4 Ağustos 2017); James Pattison, “The Ethics of Humanitarian Intervention in Libya”, Ethics \& International Affairs, Cilt 25, No.3, 2011, s.271-277.

62 BBC, "Libya Letter by Obama, Cameron and Sarkozy: Full text”, 15 Nisan 2011, http://www.bbc.com/news/worldafrica-13090646 (Erişim Tarihi 15 Mayıs 2015).

63 Haroon Siddique, "Libya Calls Ceasefire in Response to UN Resolution”, 18 Mart 2011, http://www.theguardian.com/ world/2011/mar/18/libya-ceasefire-response-un-resolution (Erişim Tarihi 10 Mayıs 2015).

6415 Şubat-18 Mart 2011 tarihleri arasında, Fransa, İngiltere ve ABD, Libya’ya müdahaleyle ilgili 146 beyanda bulunmuştur. Müdahalenin uluslararası kamuoyunun gözünde nasıl meşrulaştırıldığını ortaya koymak için bu beyanlar önemlidir. Bkz. Borjana Lubura-Winchester ve Reece Jones, “The Geopolitics of Humanitarian Intervention: The Responsibility to Protect in Libya”, The Arab World Geographer, Cilt 16, No.3, 2013, s.245-266. 
Libya müdahalesi öncesi geliştirilen "negatif söylem” ise Kaddafi'yi diktatör olarak tanımlamakta ve kendi halkına şiddet uygulaması sebebiyle Kaddafi'nin meşruiyetini yitirdiğini belirtmektedir. ${ }^{65} 1970$ sayılı kararda, Kaddafi yönetimi, "Libya otoritesi veya hükümeti” olarak nitelendirilirken, 1973 sayılı kararda sadece "otorite" söylemine yer verilmiştir. Her iki kararda da "devlet" vurgusunun yapılmaması dikkat çekicidir. Libya hükümetinin, halkını koruma sorumluluğunu yerine getiremediği fikrinden hareketle uluslararası hukuk ve güç kullanımı arasında bağlantı kurulmuştur. Libya egemen bir devlet olmaktan çıkarılarak uluslararası hukukun nesnesi olarak tanımlanmaktadır. Bu durum, koruma sorumluluğunun sınırlarını aşmakta, bir kez devletin egemenliği ve meşruluğu söylem düzeyinde ortadan kaldırılınca, rejim değişikliği kendiliğinden meşruiyet kazanmaktadır.

Libya’ya müdahale sürecinde üzerinde durulması gereken bir diğer nokta liderlerin söylemleridir. ABD Başkanı Obama’nın müdahaleye ilişkin söylemleri oldukça önemlidir. Obama 19 Mart 2011'deki açıklamalarında, ABD’nin geniş bir koalisyonun parçası olduğunu vurgulamış ve Libya'da tehdit altında bulunanların çağrılarına cevap verdiklerini ifade etmiştir. ${ }^{66} 28$ Mart 2011 tarihli açıklamalarında da, kırk yılı aşkın bir süredir Libya'nın bir "tiran” tarafından yönetildiğini, Kaddafi'nin kendi halkının özgürlügünü elinden aldığını ve muhalifleri öldürdügünü belirtmiştir. Baskıcı politikaları sebebiyle halkın güvenini yitiren Kaddafi'nin artık iktidarda kalamayacağını dile getirmiştir. ${ }^{67} \mathrm{Bu}$ söylemiyle Obama, açıkça rejim değişikliği talebini gündeme taşımış ve bu talebi geniş çaplı insan hakları ihlallerine ve şiddet olaylarına dayandırmıştır.

Bu konuşmada, uluslararası toplumun ABD’ye verdiği güçlü desteğe dikkat çekilmiş ve Kaddafi yönetimden ayrılmadıkça Libya'daki tehdidin devam edeceği vurgulanmıştır. Ayrıca, Libya'daki durumun Mısır ve Tunus'taki henüz yeterince sağlamlaşmamış barışçıl adımları olumsuz etkileyeceği belirtilerek "diktatörlüğün en karanlık biçiminin bölgedeki demokratik ilerlemeyi gölgeleyeceği" söylemlerine yer verilmiştir. Her ne kadar, rejim değişikliğinin hata olabileceğinden söz edilse de, Kaddafi'siz bir Libya’nın çok daha iyi olacağına şüphe olmadığı açıkça belirtilmiştir. ${ }^{68}$

Obama’nın söylemleri oldukça çarpıcıdır zira bu söylemler, Mutua’nın “barbarlar, kurbanlar ve kurtarıcılar” metaforuyla doğrudan örtüşmektedir. Libya müdahalesinin gerekçesi olarak ağır insan hakları ihlalleri gösterilmekte, Kaddafi diktatör olarak tanımlanmaktadır. Libya'daki muhalifler ise demokratik haklarını talep ettikleri için şiddet gören masum "kurbanlar" olarak somutlaştırılmıştır. ABD ve müttefikleri, Libya'daki "kurbanlara” demokrasi ve özgürlük götürecek medeni "kurtarıcılardır"; buna karşın Libya yönetiminde medenileşmemiş olanlar yer almaktadır. Böylece Libya’ya yapılacak olan müdahale ve hatta rejim değişikliği meşru bir zemine oturtulmaya çalışılmıştır.

TWAIL'in temel savlarından biri, Batılı devletlerin Üçüncü Dünya'ya müdahale etme konusunda misyon yüklendikleridir. Batılı devletler kültürel ve siyasal olarak kendilerinden geride olanlara Batı kimliği ekseninde devlet kurmayı öğretme hakkını kendilerinde görmekte ve bu hiyerarşi üzerinden meşruiyet sağlamaktadır. Obama’nın söylemlerinde ABD ve müttefiklerine Libya'ya müdahale konusunda sorumluluk yüklenmekte ve Libya halkına Batılı değerler ekseninde

65 Ibid., s.254.

66 Remarks by the President on Libya, 19 Mart 2011, https://obamawhitehouse.archives.gov/the-press-office/2011/03/19/ remarks-president-libya, (Erişim Tarihi 10 Mart 2017).

67 Remarks by the President in Address to the Nation on Libya, 28 Mart 2011, https://obamawhitehouse.archives.gov/thepress-office/2011/03/28/remarks-president-address-nation-libya, (Erişim Tarihi 10 Mart 2017).

68 Ibid. 
bir gelecek vaat edilmektedir. Mahdavi'ye göre, mevcut politikalar kolonyal tarihle birleşince, R2P'nin “adaletsiz hegemonik küresel düzenin” yeni bir entelektüel, yasal ve siyasal ürünü olduğu kanısı ortaya çıkmaktadır. ${ }^{69}$

Libya müdahalesine ilişkin bir diğer meşruiyet zemini BMGK kararlarıdır. Gerek 1970 gerekse 1973 sayılı kararlarda Libya yönetiminin sorumluluğuna dikkat çekildiği ancak insani krizin durdurulması konusunda sonuç elde edilemediği belirtilmiştir. Müdahale, 1973 sayılı karar dolayısıyla, "doğru otorite" kriterini sağlamaktadır. Dahası müdahale, başta Arap Birliği olmak üzere, uluslararası örgütlerden ciddi destek görmüştür. Ancak TWAIL, ana akım yaklaşımlarla Koalisyon güçlerinin hukuki savları arasında paralellik olduğu iddiasındadır. Buna göre, BMGK kararlarına yapılan vurguyla rejim değişiklikleri, geniş çaplı işgaller ve başka bir ülkede ulus inşası uygulamaları meşrulaştırılmakta, müdahale kararının hukukiliğine odaklanılarak müdahalenin içeriği göz ardı edilmektedir. $^{70}$

Libya müdahalesinin bir diğer analiz noktası 2009'da ortaya konulan üç sütunlu uygulama anlayışıdır. Birinci sütunda devletin kendi halkını koruma sorumluluğu gündeme gelmektedir. Libya'da müdahale kararı öncesinde çok sayıda kişinin hayatını kaybettiğine dair uluslararası toplumda yaygın bir görüş vardır. ${ }^{71} 1970$ sayılı BMGK kararı, Libya'da yaşananların insanlığa karşı suç seviyesine ulaşabileceğini saptamış, bu durum ilgili kararın temel gerekçesini oluşturmuştur. BM Antlaşması'nın VII. bölümünün 41. maddesine atıfta bulunan BMGK, Libya otoritelerinin sivil halkı koruma sorumluluğuna dikkat çekmiştir. Bu bağlamda, alınan karar, R2P’nin uygulama raporundaki üç sütunlu stratejinin ilk aşamasına işaret etmektedir. Bu kararla konu Uluslararası Ceza Mahkemesi (UCM)'ne taşınmış ${ }^{72}$, UCM, Muammer Kaddafi, Seyfülislam Kaddafi ve Abdullah Senussi hakkında 15 Şubat 2011'den itibaren insanlığa karşı suç işledikleri gerekçesiyle soruşturma açmış ve haklarında tutuklama kararı çıkarmıştır. ${ }^{73}$

1973 sayılı kararın oylamasının öncesinde Kaddafi Bingazi’deki isyancılara yönelik katliam olacağına dair açık ifadelerde bulunmuştur. ${ }^{74} \mathrm{Bu}$ çağrı, geniş çaplı bir insani felaketin yaşanacağı inancını arttırmıştır. 1973 sayılı kararda, Libya otoritelerinin 1970 sayılı kararı yerine getirmediğinin altı çizilmiş, Güvenlik Konseyi sivil halkı koruma konusundaki kararlığını tekrar dile getirmiştir.

1973 sayılı kararın Libya'ya müdahaleyi içermesi sebebiyle, uygulanmanın ikinci aşamasının aşıldığ görülmektedir. Nitekim BM 2005 Dünya Zirvesi Sonuç Bildirgesi’nin 138. paragrafında belirlenen kriterlerden biri olan devletin halkını "insanlığa karşı suç"lardan koruma sorumluluğu yerine getirilmemiş, gerek BM’nin gerekse bölgesel örgütlerin bu ihlallerin durdurulmasına yönelik talebi dikkate alınmamıştır. Dolayısıyla, ilgili bildirgenin 139. paragrafında yer alan ve 2009 uygulama raporunun üçüncü sütununu oluşturan “kolektif, zamanında ve kararlı eylem” aşamasına geçilmiştir.

\footnotetext{
69 Mahdavi, "A Postcolonial Critique", s.13.

70 Natarajan, "A Third World Approach", s.407.

71 Bu görüşe rağmen, Libya müdahalesinden önce kaç kişinin hayatını kaybettiğine, yaralandığına ya da işkence gördüğüne dair kesin rakamlar mevcut değildir. Bkz. Lubura-Winchester ve Jones, “The Geopolitics of Humanitarian Intervention”, s.257.

72 UNSC, Resolution 1970.

73 BBC, Libya: Muammar Gaddafi subject to ICC arrest warrant", http://www.bbc.com/news/world-africa-13927208, (Erişim Tarihi 20 Temmuz 2017).

74 Adams, "Libya and the Responsibility to Protect".
} 
$\mathrm{Bu}$ aşamalar R2P'ye uygun adımlar olarak değerlendirilse dahi müdahale birçok eleştiriyi beraberinde getirmiştir. Müdahaleye ilişkin ortak kanaat orantılılık kıstasının aşılmış olmasıdır. ${ }^{75}$ Askeri gücün, insanları koruma amacıyla minimum ölçüde kullanılması gerekirken NATO'nun tutumunun çatışmanın artmasına neden olduğuna ve şiddetin yerel faktörlerden mi yoksa uluslararası müdahaleler sonucu mu ortaya çıktığını söylemenin zorlaştığına ilişkin görüşler vardir. $^{76}$

Libya'yı önceki müdahalelerden ayıran üç temel unsurdan söz edilebilir. Birincisi, şiddetin sivil halka yönelip yönelmediğidir. Koalisyon güçlerinin beyanlarının aksine Kaddafi'nin sivil halkı hedef almadığı ve Libya'da kitlesel kıyıma yönelik kanıtların yeterince açık olmadığı iddiaları mevcuttur. ${ }^{77}$ İkincisi, Libya'ya müdahale kararı oluşacak riskler tespit edilemeden çok hızlı alınmıştır. ${ }^{78}$ Silah ambargosu, seyahat yasağı ve kaynakların dondurulması gibi önlemlerin etkisi takip edilmeden askeri müdahaleye karar verilmiştir. ${ }^{79}$ Bununla birlikte, söz konusu tedbirlerin etkili olmayacağ görüşü hâkimse Güvenlik Konseyi’nin hukuken bekleme zorunluluğunun olmadığg belirtilmelidir. Üçüncüsü ise bölgesel örgütlerin müdahaleye verdiği güçlü destektir. Nitekim Libya'da uçuşa yasak bölge ilan edilmesini, bölge örgütleri, BMGK'den talep etmişlerdir.

R2P tek taraflı müdahaleler ve insani krizlere karşı kayıtsızlık arasında denge kurmak için harekete geçirilmiş, böylece dışarıdan bir müdahalenin daha etik ve örgütsel çerçevede tanımlanabilmesi hedeflenmiştir. ${ }^{80}$ Libya'da uygulanan güç kullanımı kolektif bir girişimdir. Ancak, müdahale, Kaddafi’nin öldürülmesi ve rejim değişikliğiyle sonuçlanarak, gücün kötüye kullanımına neden olmuş ${ }^{81}$ ve uluslararası hukukun esnetilebilirliğini açığa çıkarmıştır. ${ }^{82}$

BMGK kararlarında, Libya’nın uluslararası barış ve güvenlik konusundaki sorumluluklarına dikkat çekilmesi bir diğer önemli husustur. Müdahalenin "uluslararası barış ve güvenliğin tehdidi” olarak değerlendirilmesi ve R2P'nin uygulanması sebebiyle hukuki olduğu öne sürülebilir. Ancak, rejim değişikliği açık bir şekilde uluslararası hukuk ilkelerine aykıııdır. 1973 sayılı karar alınışı itibariyle hukuki olsa da, uygulanan gücün miktarı ve yoğunluğu bakımından müdahale kararının yetkilerini aşmış, müdahale öncesinde ve sırasında üretilen söylemlerle kurulan meşruiyet zemini önemli ölçüde zarar görmüştür.

75 Jamie Herron, "Responsibility to Protect: Moral Triumph or Gateway to Allowing Powerful States to Invade Weaker States in Violations of the U.N. Charter?", Temple International \& Comparative Law Journal, Cilt 26, No.2, 2012, s.367-389.

76 Natarajan, "A Third World Approach", s.412.

77 Bkz. Alex J. Bellamy, "Libya and the Responsibility to Protect: The Exception and the Norm", Ethics \& International Affair, Cilt 25, No.3, 2011, s.265; Alan J. Kuperman, "A Model Humanitarian Intervention? Reassessing NATO's Libya Campaign", International Security, Cilt 38, No.1, 2013, s.108-110.

78 Bellamy, "Libya”, s.266.

79 Niels Rijke, “Intervention in Libya: A crime of aggression?”, International Crimes Database (Brief 4), Mart 2014, http:// www.internationalcrimesdatabase.org/upload/documents/20140916T170326-ICD\%20Brief\%204\%20-\%20Rijke.pdf (Erişim Tarihi 30 Mayıs 2015).

80 Ramesh Thakur, “Has R2P Worked in Libya?”, 19 Eylül 2011, http://www.canberratimes.com.au/federal-politics/ editorial/has-r2p-worked-in-libya-20110918-1wqqb.html (Erişim Tarihi 20 Mayıs 2015).

81 Libya 18 Mart'ta ateşkes ilan etmesine rağmen, Bingazi’nin kuşatılmasına devam edildi. 19 Mart'ta başlayan NATO hava saldırıları 27 Ekim’e kadar sürdü. NATO'nun desteğiyle isyancılar ülkenin kontrolünü sağladı ve 20 Ekim'de Kaddafi öldürüldü.

82 İnsani krizleri önlemek için yapılan müdahaleler, kaçınılmaz olarak müdahale edilen ülkelerin yönetimlerinde siyasi etki yaratır. Bu etkinin boyutu, insani krizin derinliği, niteliği, tarafları ve müdahale edenin politikaları çerçevesinde belirlenir. Örneğin Bosna müdahalesi (1995), Bosnalı Sırp liderliğinin tasfiyesi ve Dayton düzeniyle, Kosova müdahalesi (1999) ise Kosova'nın Sırbistan'dan ayrılmasıyla sonuçlanmıştır. 
Batılı devletler, insanları korumak için askeri güç kullandığını ve baskıcı bir devlet aygıtını çözdüğ̈̈ü iddia ederken yerine o ülke halklarının tercih ve iradelerini yansitan yeni bir düzen kurma aşamasında yetersiz kalmıştır. ${ }^{83}$ Mevcut süreçte, hiyerarşi yeniden hem kültürel üstünlük söylemiyle hem de askeri güç kullanımıyla üretilmiştir. Burada, kolonyal dönemin karşıtlıklarının devam ettiği göze çarpmakta, otoriter rejimler ile kurban halkı savunan Batılı ülkeler ikilemi açık bir şekilde varlı̆̆ını sürdürmektedir. Devletlerin değil halkların çıkarlarının öne çıkarılması savunulurken, doğrudan Libya halkı en çok zarar gören taraf olmuştur.

\section{Sonuç}

Batı'nın uluslararası sistemde kendi lehine işleyen hiyerarşik düzeni devam ettirme sürecinde müdahale pratikleri önemli bir yere sahiptir. TWAIL, uluslararası hukuka ilişkin tartışmasını tarihsel bir temele dayandırmakta, insani müdahale ve R2P gibi kavramları bu temel üzerinden yorumlamaktadır. $\mathrm{Bu}$ bağlamda, uluslararası hukuku, Avrupa-merkezciliğin sürdürülmesinde araç olarak değerlendirmekte, demokratik-otoriter, medeni-medenileşmemiş, Batı-Doğu gibi ikilikler üzerinden uluslararası hukuk pratiklerinde gizli kalmış vurguları açığa çıkarmaktadır. Libya müdahalesinin söylemsel meşrulaştırıcı çerçevesini oluşturan R2P de bu eleştirilere dâhil edilmiş ve Batı́nın Üçüncü Dünya devletlerine yapacağı müdahalelerde R2P’yi bir araç olarak kullandığı ileri sürülmüştür. Böylece uluslararası hukukun işleyişinde Batı merkezli bir hiyerarşinin temel alındığı dile getirilmiştir.

TWAIL, sadece ABD ile müttefiklerinin hukuki savlarına odaklanmayıp daha geniş bir uluslararası hukuk okumasının yapılması gerekliliği üzerinde durmakta ve Batı́nın Üçüncü Dünya’ya yönelik savlarıyla, uluslararası hukukun temelinde yatan mantık arasında paralellik kurmaktadır. Hukuki normlar ekseninde kurgulanan ve BMGK kararıla harekete geçirilen Libya müdahalesi de uluslararası toplumun güçlü desteğini almasına rağmen, süreç içinde hem hukuk hem de meşruiyet sınırlarını aşmıştır. Libya’da Koalisyon'un savları uluslararası hukukun temel prensipleriyle çelişmiş ve Üçüncü Dünya'ya yapılacak askeri bir müdahalenin yalnızca BMGK kararlarınca meşrulaştırılmasının yetersizliğini ortaya çıkarmıştır.

TWAIL'in temel özelliklerinden biri, uluslararası hukuk düzenini yalnızca analiz etmekle yetinmeyerek onun nasıl ve hangi yönde dönüştürülmesi gerektiğini de gösteren normatif bir yön içermesidir. Bu çerçevede yürüttüğü meşruiyet tartışmasının bir diğer önemli noktası, uluslararası hukuka ilişkin söylemlerin kültürel farklılık söylemleri ekseninde kurulduğunu göstermiş olmasıdır. Bu bağlamda, Libya müdahalesi de "biz ve öteki” ayrımı üzerinden şekillenmiş, Batılı değerler merkeze alınmış ve Batı-Doğu arasındaki kültürel ve siyasi hiyerarşinin devamlılığı sağlanmıştır.

R2P kapsamında güç kullanımının ilk somut örneği olan Libya müdahalesi, insani krizleri önlemeye yönelik askeri müdahalelerin hukuki ve ahlaki zeminde, nasıl hızlı ve etkili bir şekilde meşrulaştırılacağını gözler önüne sermiştir. R2P’nin ayırıcı özelliği tepki gösterme sorumluluğundan ziyade önleme sorumluluğu çerçevesinde tanımlanmasıdır. Dolayısıyla, askeri operasyonlara son çare olarak başvurma seçeneği ön plana çıkmalıdır. İnsani krizleri önlemek için yapılan müdahalelerde,

83 ABD Başkanı Obama, Libya’da müdahale sonrası bir düzen kurulamadığını kabul etmekte ve buna neden olarak coğrafi yakınlıklarına rağmen Avrupalı müttefiklerin ilgisizliğini ve Libya’nın iç dinamiklerini göstermektedir. Obama, Libya müdahalesinin çok iyi planlanmış olduğunu, Avrupalı müttefiklerle birlikte BMGK’nin yetkilendirmesi ile harekete geçirildiğini ve olası uzun ve kanlı bir iç savaşın önlenmiş olduğunu söylemekte ancak buna rağmen, Libya'daki müdahale sonrası durumu bir "karmaşa" hatta bir "facia" olarak tanımlamaktadır. Bkz Jeffrey Goldberg, "The Obama Doctrine", The Atlantic, Nisan 2016, https://www.theatlantic.com/magazine/archive/2016/04/the-obama-doctrine/471525/ (Erişim Tarihi 5 Ağustos 2017). 
müdahalenin amacı ile süreç içinde gerçekleşen eylemlerin ve süreç sonunda ortaya çıan sonuçların paralellik göstermesi gerekmektedir. Müdahaleler adil uluslararası normlarla çevrelendiği takdirde, insani krizlerin, rejimleri düşürmek için gerekçe olarak sunulması engellenebilir.

Libya müdahalesi, yeni, daha adil, Üçüncü Dünya’nın bir özne olarak var olabileceği, madunu koruyan, bu anlamda çoğulculuğun önünü açan bir uluslararası hukuk tahayyülünü yıkması anlamında çarpıcı bir etki yaratmıştır. Müdahale, BMGK kararları üzerinden uluslararası hukuk normlarının evrenselliğini yeniden kurmuş, bir meşruiyet aracı olarak uluslararası hukukun uluslararası hiyerarşiyi teyit etmesini sağlamışıı. Böylece müdahale, akademik olarak TWAIL tartışmalarını haklı çıarırken, siyaseten var olan eşitsiz ve Üçüncü Dünya’nın müdahaleye açık uluslararası yapılanmasının devam ettiğini göstermesi açısından normatif ve politik bir geriye düşüşü temsil etmektedir. 